\title{
Nipa (Nypa fruticans Wurmb) Sap Collection in Southern Thailand II. Biomass and Soil Properties
}

\author{
Naohiro Matsui ${ }^{1}$, Yasuyuki Okimori ${ }^{2}$, Fumio Takahashi ${ }^{1}$, Koji Matsumura $^{3} \&$ Noparat Bamroongrugsa $^{4}$ \\ ${ }^{1}$ Environment Department, The General Environmental Technos Co., Ltd., Osaka, Japan \\ ${ }^{2}$ Business Department, The General Environmental Technos Co., Ltd., Osaka, Japan \\ ${ }^{3}$ Power Engineering R\&D Center, The Kansai Electric Power Co., Inc., Kyoto, Japan \\ ${ }^{4}$ Faculty of Environment Management, Princes of Songkla University, Hat Yai, Thailand \\ Correspondence: Naohiro Matsui, Environment Department, The General Environmental Technos Co., Ltd., 1-3-5 \\ Azuchimachi, Chuo-ku, Osaka 541-0052, Japan. Tel: 81-662-637-314. E-mail: matui_naohiro@kanso.co.jp
}

\author{
Received: July 30, 2014 Accepted: August 15, 2014 Online Published: September 4, 2014 \\ doi:10.5539/enrr.v4n4p89 URL: http://dx.doi.org/10.5539/enrr.v4n4p89
}

\begin{abstract}
Nipa (Nypa fruticans Wurmb) frond biomass is the cruicial factor for sap/sugar production. An allometric equation was firstly formulated for estimating frond biomass from the length (L) and the diameter at breast height (DBH) of a frond. And subsequently the L-DBH relationship was applied for L estimation at five nipa farms. As a result, the allometric equation was expressed as $\log \mathrm{DW}=0.85 \times \log \mathrm{D}^{2} \mathrm{~L}+1.54\left(\mathrm{r}^{2}=0.94\right)$. The highest above-ground biomass was $83 \mathrm{t} / \mathrm{ha}$, whereas the average biomass in other farms was $32 \mathrm{t} / \mathrm{ha}$, which was almost the same as that in young oil palm plantation. The physical and chemical properties of soils in the nipa farms were analyzed using 80 soil samples to elucidate the factors determining nipa soil properties by principle component analysis (PCA). Consequently, organic matter, salt content and brackish water were considered to be the key factors determining nipa soil properties. Daily sap production ( $\mathrm{ml} /$ day) (DSP) was well explained by frond biomass and above-ground biomass with the equations: DSP $=17.6 \mathrm{x}$ frond biomass $(\mathrm{kg})+256.1\left(\mathrm{r}^{2}=0.48\right)$ and DSP $=11.4 \mathrm{x}$ above-ground biomass $(\mathrm{t} / \mathrm{ha})+263.4\left(\mathrm{r}^{2}=0.57\right)$, respectively. When soil properties are included, sap production is better explained, as shown by multivariate analysis followed by PCA with the equation, DSP $=609.7-92.9 \times \mathrm{PC} 1-58.5$ x PC2 $\left(r^{2}=0.93\right)$. As PC1 and PC2 correspond to the organic matter factor and the salt content factor, sap production would be controlled by the nipa growth and the amount of $\mathrm{Na}$ in soil.
\end{abstract}

Keywords: allometric relationship, biomass, nipa, soil properties

\section{Introduction}

From the examination on the sap and sugar productivity of nipa (Nypa fruticans Wurmb), it was elucidated that nipa farming could be a promising practice in tropical coastal areas because it produces sap sustainably. The growth properties of the nipa fruit stalk, as well as the water status, were shown to affect sap production. Taking these into account, more detailed studies about other factors regulating nipa growth and sap production are required to draw more attention to the incorporation of nipa to an integrated coastal management.

Since sap is a product of photosynthesis, frond (leaf) biomass is likely related to sap production. Many biomass studies have been carried out on other palms such as coconut and oil palm (Henson \& Chai, 1997; Fangren et al., 1999; Khalid et al., 1999; Thenkabail et al., 2004; Shuit et al., 2009; Morel et al., 2011), but there are scarcely any studies of nipa biomass. Tree/plant biomass has been measured by a destructive method involving the cutting off of an entire plant and weight measurement after partitioning. Moreover, above-ground biomass can be easily estimated by a method established by Corley et al. (1971) with some accuracy from allometric relationships between plant height and diameter. Allometric equations were formulated for oil palm (Aholoukpè et al., 2013) and coconut (Navarro et al., 2008; Brakas \& Aune, 2011), but not yet for nipa. Hence, we firstly intended to establish an allometric equation for nipa biomass estimation in the area where we conducted sap monitoring.

Soil is an important component of the environment, functioning not only as a substrate but also as source of nutrients for plant growth. The distribution of mangrove species is affected by topography (Komiyama et al., 1996, Kitaya et al., 2002), and the growth of the mangrove species Rhizophora apiculata is regulated by up to $90.3 \%$ by soil conditions (Matsui et al., 2008). Moreover, soil properties affect palm growth in coconut 
(Arachchi \& Liyanage, 1997) and oil palm plantations (Auxtero \& Shamshuddin, 1991; Khalid \& Anderson, 2000). Soil conditions may thus have an impact on nipa growth and sap production; therefore, soil properties in a nipa stand is worth studying.

The objectives of this study were hence 1) to determine the biomass of nipa stands by formulating an allometric relationship, 2) to understand the soil properties of nipa stands, and 3) to examine the effects of biomass and soil properties on sap production.

\section{Methods}

\subsection{Study Site and Frond Measurement}

Biomass and soil studies were conducted in the same place where sap/sugar monitoring was conducted, Pak Phanang Basin in Nakorn Si Thammarat Province in southern Thailand (Part I; Figure 1). For this study, other farms were also studied in addition to those studied for sap/sugar monitoring.

A monitoring plot of $20 \mathrm{~m} \times 20 \mathrm{~m}$ was established within a nipa plantation for measuring frond biomass at five nipa farms including three farms studied for sap/sugar production (Part I; Table 1). All individual fronds within the plot were tagged, counted, and numbered randomly for measuring frond diameter at breast height (DBH) and frond length (L) (Figure 1). For four farms, a crown projection diagram was prepared to display the locations of fronds growing or held together (which is called as cluster, Part I; Figure 10).

\subsection{Estimates of Above-Ground Biomass of Nipa Stands From Allometric Equation}

\subsubsection{Allometric Equation Formulation}

Ten fronds in Kovit's farm were selected from the various sizes of small to large lengths for formulating allometric equation. Immediately after cutting off whole fronds of nipa, their fresh weight, L, and DBH were measured. Subsequently, their rachis and leaves were separated (Figure 1). They were brought back to the laboratory for complete drying at $120^{\circ} \mathrm{C}$ for 48 hours in the oven. Allometric equation for estimating biomass on dry weight basis (DW) were formulated from the measured biophysical properties of fronds, namely, DBH and L.

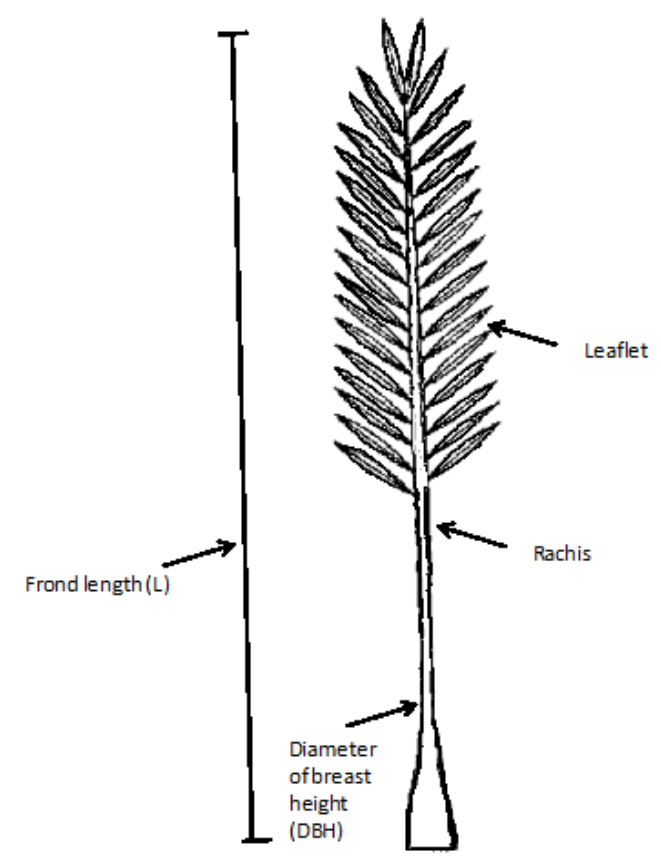

Figure 1. Diagram of nipa frond. Frond is divided into two parts, the leaf and rachis. For biomass measurement, $\mathrm{DBH}$ and $\mathrm{L}$ are measured

The diameter of a rachis differs depending on the part of the rachis measured (Figure 1); thus, the diameter was measured at four different heights: at the base and at $100 \mathrm{~cm}, 130 \mathrm{~cm}$, and $160 \mathrm{~cm}$ above the ground in Bunchoy's farm. The values obtained were compared to determine the part of the rachis whose diameter correlates most with the $\mathrm{L}$ of fronds. 


\subsubsection{Above-Ground Biomass Measurement of Nipa Stands}

To calculate above-biomass using an allometric equation, the DBH and $\mathrm{L}$ of all fronds were measured within the plots prepared for frond measurement either at the end of August or in September for three years, 2010, 2011 and 2013.

Regarding DBH and L in the allometric equation, DBH is easy to measure in a farm, but L measurement is rather time-consuming because fronds are mostly inclined and their Ls sometimes exceed $10 \mathrm{~m}$. Thereby, the relationship between DBH and $\mathrm{L}$ was obtained to derive $\mathrm{L}$ from DBH. Because frond shape varies with time and space, the relationship between these variables was examined for each farm.

The biomass of fronds surrounding a fruit stalk being tapped for sap was estimated using the allometric equation formulated in this study to examine the relationship between frond biomass and sap production. At three farms, 2 or 3 fruit stalks were selected for monitoring sap production from 16 to 53 days. For each fruit stalk, the DBH and $\mathrm{L}$ of all the surrounding fronds, which are either 4 or 5 , were measured for biomass estimation.

\subsection{Soil Sampling and Analysis}

In 2010, we collected 16 soil samples from each of the five farms. A total of 80 samples were analyzed for moisture content, $\mathrm{pH}, \mathrm{EC}$, exchangeable $\mathrm{Mg}, \mathrm{Ca}, \mathrm{K}$, and $\mathrm{Na}$ contents, and total $\mathrm{C}$ and $\mathrm{N}$ contents. Moisture content was calculated by heating at $105{ }^{\circ} \mathrm{C}$ for 48 hours using a $100 \mathrm{cc}$ volumetric cylinder. Samplings for moisture content were conducted within $30 \mathrm{~min}$ after water receded from the site. $\mathrm{pH}$ and EC were measured after shaking fresh soil samples for 1 hour at a soil-to-water ratio of 1:10 using a Beckman $\Phi 72$ and a CyberScan Con300, respectively. Total $\mathrm{C}$ and $\mathrm{N}$ contents were determined by the dry combustion method (NC-analyzer, 1000; Sumigraph, Shimadzu, Kyoto, Japan) and the C-to-N ratio was calculated. Dry soil samples were prepared by shaking them with $1 \mathrm{~N}$ ammonia acetate then measured for exchangeable $\mathrm{Ca}, \mathrm{Mg}, \mathrm{Na}$, and $\mathrm{K}$ contents by the atomic absorption method (Shimadzu A-6000, Kyoto, Japan).

\subsection{Statistical Analysis}

For analytical results of the 80 soil samples, descriptive statistics, the mean, maximum, and minimum values, and the coefficient of variation of each soil property were calculated. Correlation analysis was also conducted for all datasets. Principal component analysis (PCA) of the soil properties was conducted to summarize data and investigate the relationships among the properties (Kosaki \& Juo, 1989). Using the mean values of soil analysis, above-ground biomass and mean daily sap production at the five farms, correlation analysis and multivariate analysis were conducted. Statistical analysis was conducted using the software JMP 8.0.2 version for Windows (SAS Inc., 2009).

\section{Results}

\subsection{Number of Fronds and DBH}

The average number of fronds within a plot of $20 \mathrm{~m}$ x $20 \mathrm{~m}$ was 542, that is, 13,550 fronds/ha (Table 1). The numbers of fronds were almost the same in three years in Kovit, Sompong, and Bunchay's farms, but fluctuated yearly in Yong Yot's farm. Farmers conduct thinning of fronds as a conventional practice; thus, the number of fronds always change. Moreover, management practices vary among farms, resulting in differences in frond number.

The number of clusters was the lowest ( $\mathrm{n}=29 ; 725$ clusters/ha) in Kovit's farm, whereas Sompong's farm had 42 (1,050 clusters/ha) and Yong Yot's farm had 40 (1,000 clusters/ha) (Figure 2). Although Kovit's farm had the lowest number of clusters, the number of fronds was not markedly different from those in the other farms, which means that a cluster in Kovit's farm was larger than those in the other farms. A larger cluster in Kovit's farm corresponds to a larger frond DBH $(6.8 \mathrm{~cm})$ than in the other farms (mean DBH; $4.6 \mathrm{~cm})$. In contrast, Kan's farm had a highest number of fronds but the smallest DBH among the farms. 
Table 1. Number of fronds, DBH and biomass

\begin{tabular}{|c|c|c|c|c|c|c|}
\hline Farm owner & & & 2010 & 2011 & 2012 & $\begin{array}{l}\text { Average } \\
\text { in } 3 \text { years }\end{array}$ \\
\hline \multicolumn{7}{|l|}{ Kovit } \\
\hline & Total No. of fronds* & & 514 & 554 & 547 & 538 \\
\hline & $\mathrm{DBH}(\mathrm{cm})^{* *}$ & & 6.75 & 6.82 & 6.74 & 6.77 \\
\hline & & Stdv & 1.63 & 1.55 & 1.56 & \\
\hline & DW $(\mathrm{t} / \mathrm{ha})^{* * *}$ & & 64.3 & 83.8 & 72.5 & 73.5 \\
\hline \multicolumn{7}{|l|}{ Sompong } \\
\hline & Total No. of fronds & & 480 & 561 & 432 & 491 \\
\hline & DBH (cm) & & 4.55 & 4.59 & 4.26 & 4.47 \\
\hline & & Stdv & 0.66 & 0.76 & 0.86 & \\
\hline & DW (t/ha) & & 24.3 & 30.2 & 27.6 & 27.4 \\
\hline \multicolumn{7}{|l|}{ Yong Yot } \\
\hline & Total No. of fronds & & 397 & 625 & 489 & 504 \\
\hline & $\mathrm{DBH}(\mathrm{cm})$ & & 4.82 & 4.90 & 4.77 & 4.83 \\
\hline & & Stdv & 1.19 & 1.10 & 1.30 & \\
\hline & DW (t/ha) & & 27.4 & 40.1 & 35.8 & 34.4 \\
\hline \multicolumn{7}{|l|}{ Bunchoy } \\
\hline & Total No. of fronds & & 519 & 516 & 521 & 519 \\
\hline & DBH (cm) & & 4.60 & 4.61 & 4.50 & 4.57 \\
\hline & & Stdv & 0.77 & 0.80 & 0.81 & \\
\hline & DW (t/ha) & & 27 & 30.3 & 32.1 & 29.8 \\
\hline \multicolumn{7}{|l|}{ Kan } \\
\hline & Total No. of fronds & & & 611 & 703 & 657 \\
\hline & $\mathrm{DBH}(\mathrm{cm})$ & & & 3.99 & 4.15 & 4.07 \\
\hline & & Stdv & & 0.71 & 1.48 & \\
\hline & DW (t/ha) & & & 21.1 & 40.8 & 31.0 \\
\hline Average & Total No. of fronds & & & & 542 & 542 \\
\hline \multirow[t]{2}{*}{ in 5 farms } & $\mathrm{DBH}(\mathrm{cm})$ & & & & 4.94 & 4.94 \\
\hline & DW (t/ha) & & & & 39.2 & 39.2 \\
\hline
\end{tabular}



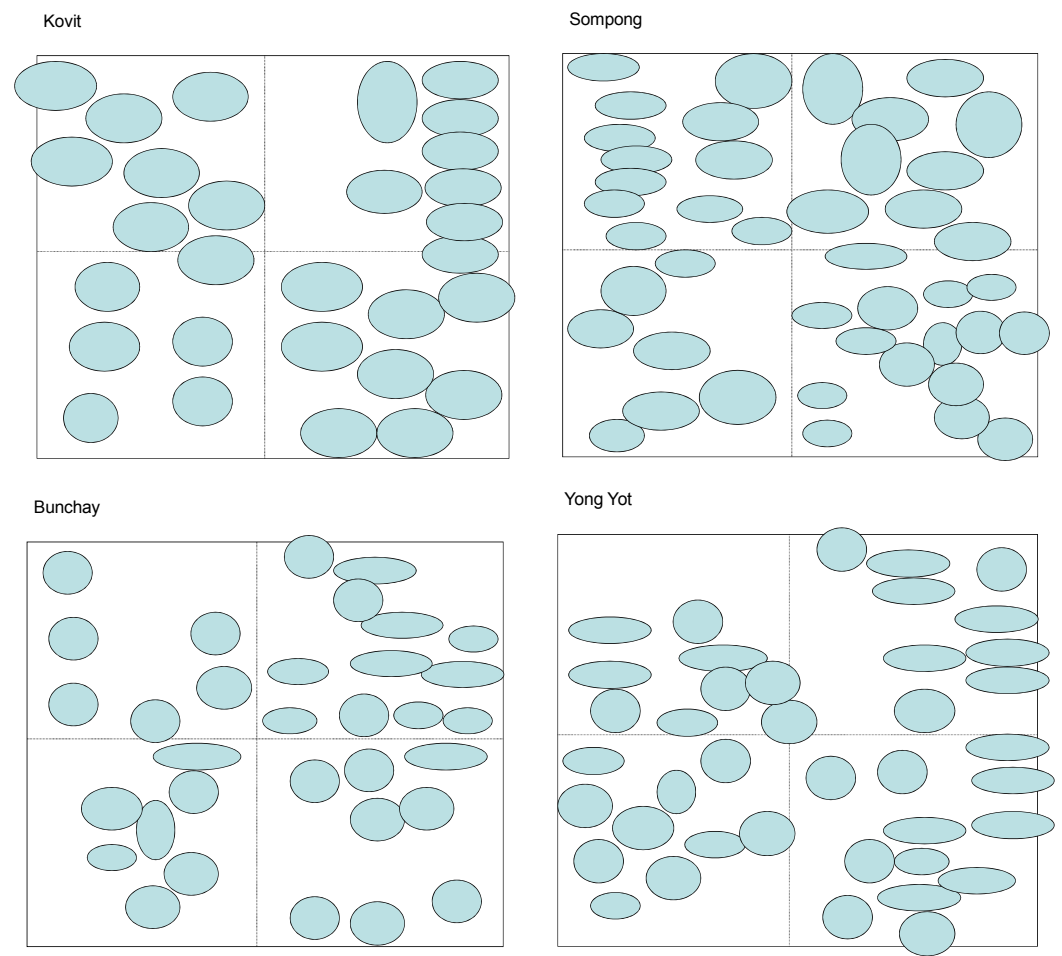

Figure 2. Crown projection diagram of nipa fronds in four farms. A circle indicates a cluster of fronds

Figure 3 shows the proportion of tagged fronds in three different years. Fronds tagged in 2010 aged at least more than 3 years were nearly $30 \%$ out of all fronds in Kovit's farm. However, the tagged fronds were only 5\% in Kan's farm. However, young fronds tagged in 2012 were only $40 \%$ in Kovit's farm, whereas nearly $50 \%$ in Sompong, Yong Yot, and Kan's farms were young fronds.

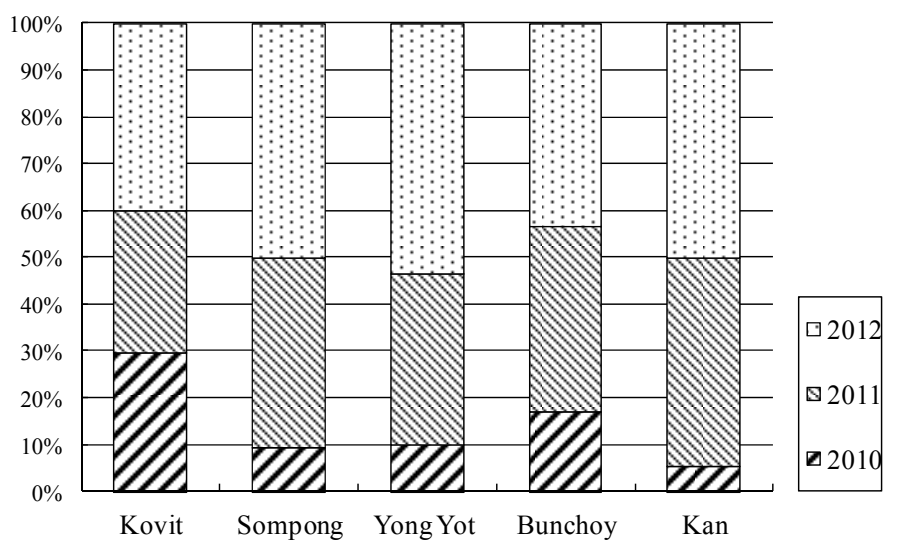

Figure 3. Number of fronds measured in $20 \mathrm{~m}$ x $20 \mathrm{~m}$ block for three consecutive years, 2010, 2011 and 2012

\subsection{Allometric Equation Formulation}

The diameters at four different heights [Base, $100 \mathrm{~cm}, 130 \mathrm{~cm}(\mathrm{DBH})$, and $150 \mathrm{~cm}$ ] were measured to determine the part of the rachis whose diameter correlates the most with $\mathrm{L}$. The diameters at the base and $160 \mathrm{~cm}$ above the ground did not correlate well with L, showing $\mathrm{r}^{2}=0.001, \mathrm{r}^{2}=0.29$, respectively, but DBH showed the highest correlation with $\mathrm{L}\left(\mathrm{r}^{2}=0.58\right)$ (Figure 4). Hence, we adopted DBH for biomass estimation in this study.

The L-DBH relationship was obtained for all the farms as follows:

Kovit: $\log \mathrm{L}=0.63 \times \log \mathrm{DBH}+2.40\left(\mathrm{n}=55, \mathrm{r}^{2}=0.42\right)$;

Sompong: $\log \mathrm{L}=0.83 \times \log \mathrm{DBH}+2.19\left(\mathrm{n}=483, \mathrm{r}^{2}=0.77\right)$;

Yong Yot: $\log \mathrm{L}=0.71 \times \log \mathrm{DBH}+2.26\left(\mathrm{n}=56, \mathrm{r}^{2}=0.56\right)$; and

Bunchoy: $\log \mathrm{L}=1.23 \times \log \mathrm{DBH}+1.95\left(\mathrm{n}=190, \mathrm{r}^{2}=0.77\right)$. 

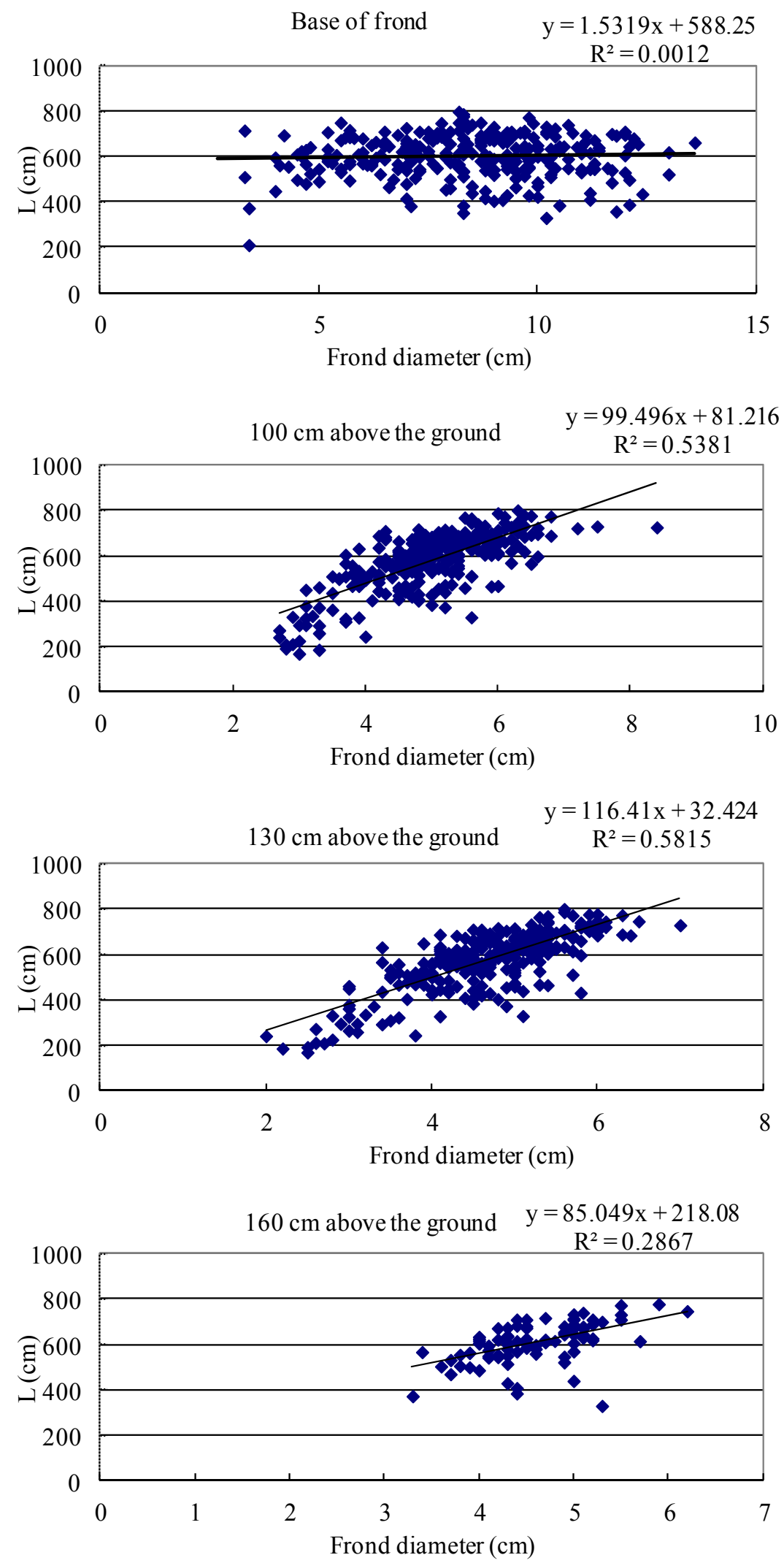

Figure 4. Relationships between frond diameter measured at different heights and L.

Since $\mathrm{L}$ affects biomass estimation, we used the equation corresponding to each farm for calculating biomass in each farm. 
From ten fronds, the allometric equation for nipa was determined for the rachis, leaf, and whole frond (rachis + leaf). The coefficient $\left(\mathrm{r}^{2}\right)$ of the equation for the leaf was low but those for the rachis and whole frond were high, 0.94 (Figure 5). Consequently, the following equation was used for biomass calculation.

$$
\log \mathrm{DW}=0.85 \times \log \mathrm{D}^{2} \mathrm{~L}+1.54\left(\mathrm{r}^{2}=0.94\right)
$$

Total

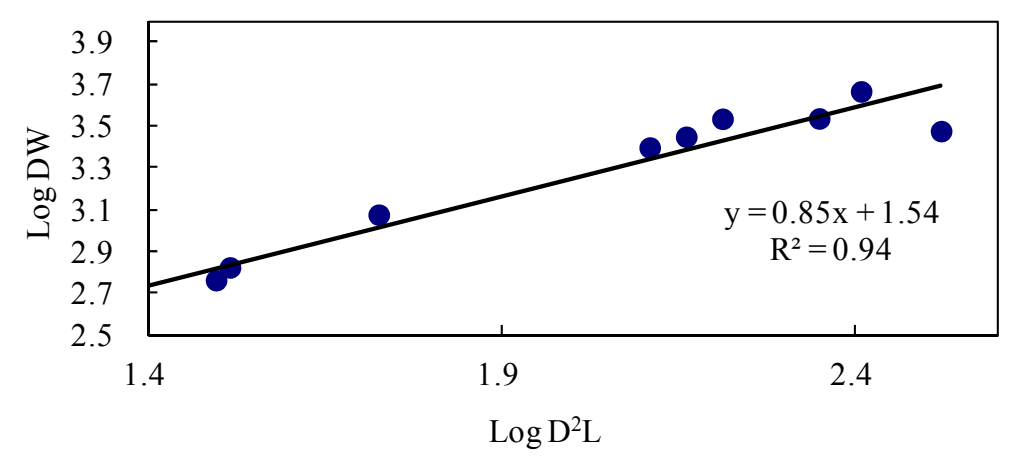

Rachis

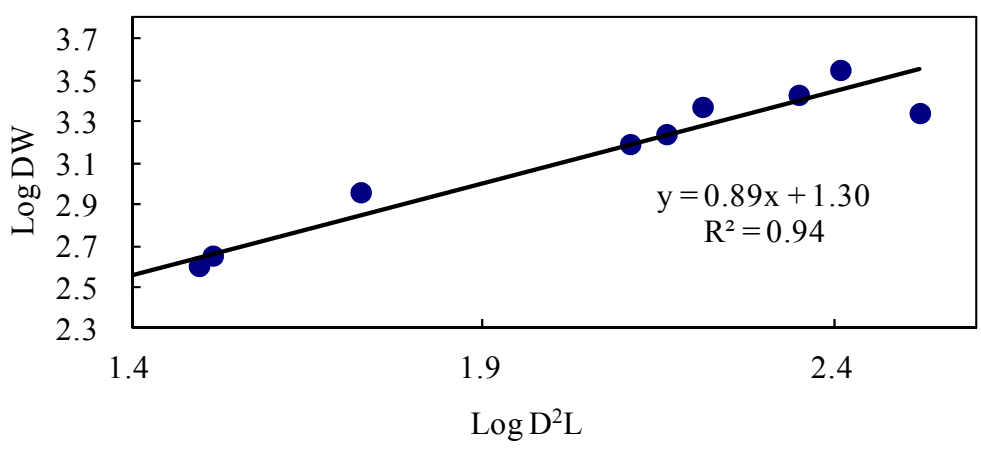

Leaflet

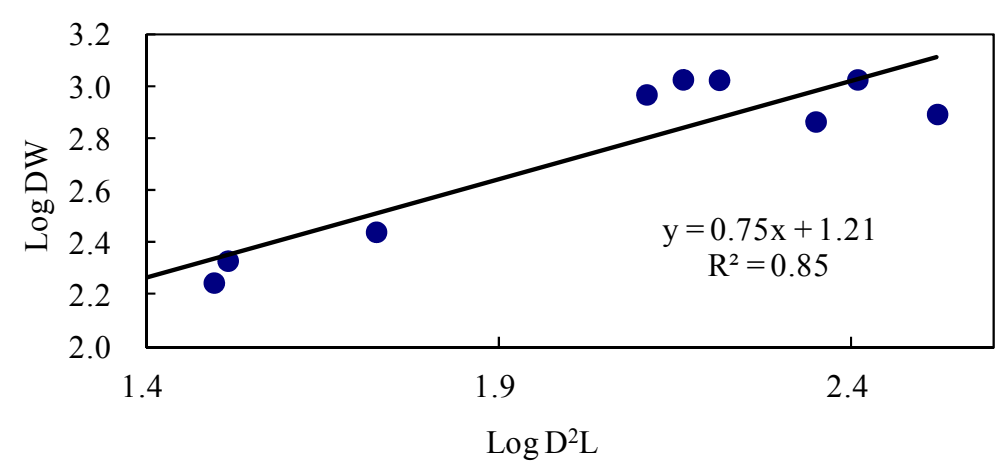

Figure 5. Allometric relationship formulated for rachis, leaf and whole frond (rachis + leaf)

\subsection{Above-Ground Biomass Measurement}

Table 1 shows the above-ground biomasses obtained using Equation (1). The highest total biomass of $83.8 \mathrm{t} / \mathrm{ha}$ was observed in Kovit's farm whose value was especially high comparing to other farms. Biomass changed yearly because of the natural growth of fronds and thinning practiced by farmers.

For the fronds surrounding a fruit stalk with on-going sap collection, biomass was measured using Equation (1). Accordingly, the biomasses of fronds surrounding the fruit stalk were as follows: YY6, $25.3 \mathrm{~kg}$; YY8, $14.5 \mathrm{~kg}$ for Yong Yot's farm; Kan8, $5.7 \mathrm{~kg}$; Kan9, $12.3 \mathrm{~kg}$ for Kan's farm; and Kasem6, $5.4 \mathrm{~kg}$; Kasem8, $9.1 \mathrm{~kg}$; Kasem6, $5.2 \mathrm{~kg}$ for Kasem's farm (Table 2). 
Table 2. Biomasses of the fronds surrounding fruit stalks

\begin{tabular}{lrrrrrrr}
\hline & \multicolumn{3}{c}{ Kasem } & \multicolumn{2}{c}{ Kan } & \multicolumn{2}{c}{ Yong Yot } \\
\cline { 2 - 7 } & Palm 6 & Palm 7 & Palm 8 & Palm 8 & Palm 9 & Palm 6 & Palm 8 \\
\hline Mean daily sap producion (ml) & 301.7 & 520.8 & 280.4 & 291.2 & 729.4 & 654.7 & 378.6 \\
Number of fronds & 5.0 & 5.0 & 5.0 & 4.0 & 5.0 & 4.0 & 4.0 \\
Biomass (DW kg) & 5.3 & 9.1 & 5.2 & 5.7 & 12.3 & 25.3 & 14.5 \\
Days of sap collection & 23 & 23 & 23 & 16 & 17 & 54 & 28 \\
\hline
\end{tabular}

\subsection{Descriptive Statistics of Measured Soil Properties}

Table 3 shows the descriptive statistics of soil properties measured in 80 samples. The coefficient of variance suggests that $\mathrm{EC}$ and $\mathrm{CN}$ showed a higher variability than the other soil properties, whereas $\mathrm{pH}$ showed a low variability. $\mathrm{pH}$ showed a statistically significant negative relationship with Total $\mathrm{C}$ and Total $\mathrm{N}$ and a positive relationship with exchangeable $\mathrm{Mg}(p<0.01)$ in the correlation matrix of measured soil properties (Table 4).

Table 3. Descriptive statistics of measured soil properties

\begin{tabular}{lrrrr}
\hline & Mean & Minimum & Maximum & CV (\%) \\
\hline Moisture & 39.6 & 14.6 & 57.3 & 24.5 \\
$\mathrm{pH}$ & 5.9 & 3.52 & 7.11 & 18.4 \\
$\mathrm{EC}(\mathrm{mS} / \mathrm{m})$ & 115.0 & 0 & 1760 & 189.8 \\
Exchangeable $\mathrm{Mg}\left(\mathrm{cmol} \mathrm{kg}^{-1}\right)$ & 88.4 & 32.5 & 176.4 & 29.9 \\
Exchangeable $\mathrm{Ca}\left(\mathrm{cmol} \mathrm{kg}^{-1}\right)$ & 68.6 & 23.7 & 108.3 & 23.5 \\
Exchangeable $\mathrm{Na}\left(\mathrm{cmol} \mathrm{kg}^{-1}\right)$ & 141.4 & 8.7 & 451.9 & 76.8 \\
Exchangeable $\mathrm{K}\left(\mathrm{cmol} \mathrm{kg}^{-1}\right)$ & 17.2 & 8 & 27.3 & 23.6 \\
Total C $(\%)$ & 4.0 & 0.49 & 15.7 & 53.3 \\
Total $\mathrm{N}(\%)$ & 0.32 & 0.11 & 0.72 & 35.2 \\
C to N ratio & 12.1 & 2.9 & 15.7 & 180.2 \\
\hline
\end{tabular}

Table 4. Correlation matrix of soil properties

\begin{tabular}{|c|c|c|c|c|c|c|c|c|c|}
\hline & $\mathrm{pH}$ & EC & Total C & Total N & $\mathrm{CN}$ & Ex. Ca & Ex. $\mathrm{Mg}$ & Ex. K & Ex. Na \\
\hline Moisture & $-0.38^{*}$ & 0.19 & 0.20 & $0.23^{* *}$ & 0.07 & -0.21 & -0.01 & $0.38^{*}$ & $0.37 *$ \\
\hline $\mathrm{pH}$ & & 0.17 & $-0.52 *$ & $-0.55^{*}$ & $-0.33 *$ & 0.11 & $0.65^{*}$ & 0.21 & $0.30^{*}$ \\
\hline $\mathrm{EC}$ & & & 0.02 & -0.02 & 0.12 & -0.06 & $0.27 * *$ & 0.20 & $0.23^{* *}$ \\
\hline Total C & & & & $0.89^{*}$ & $0.74 *$ & $0.26^{* *}$ & $-0.25 * *$ & -0.09 & -0.13 \\
\hline Total N & & & & & $0.42 *$ & 0.21 & $-0.28 * *$ & -0.07 & -0.13 \\
\hline $\mathrm{C}$ to $\mathrm{N}$ ratio & & & & & & $0.24 * *$ & -0.07 & -0.08 & -0.05 \\
\hline Exchangeable $\mathrm{Ca}$ & & & & & & & $0.31 *$ & 0.16 & -0.12 \\
\hline Exchangeable $\mathrm{Mg}$ & & & & & & & & $0.55^{*}$ & $0.68^{*}$ \\
\hline Exchangeable $\mathrm{K}$ & & & & & & & & & $0.63^{*}$ \\
\hline
\end{tabular}

* and ** indicate $1 \%$ and $5 \%$ levels of significance, respectively.

Principle component analysis (PCA) identified three components (PC1-3) with eigenvalues, or the variances of components, greater than 1.0. Three components accounted for $71.8 \%$ of the total variance (Table 5). On the basis of the component loadings without rotation, the first component showed high loadings for $\mathrm{pH}$, Total $\mathrm{C}$, Total $\mathrm{N}$ and exchangeable $\mathrm{Ca}$ content. Similarly, the second component showed high loadings for exchangeable $\mathrm{Na}$ and $\mathrm{K}$ contents, the third component for exchangeable Mg and moisture contents. Such variations of the soil properties 
are summarized into three factors, which were independent of each other. Considering the properties of each of the components, $\mathrm{PC} 1, \mathrm{PC} 2$ and $\mathrm{PC} 3$ are the components that could be related to organic matter, brackish water and frond residue, respectively.

Table 5. component loadings, eigenvalues and $\%$ of total variance explained by the first three components

\begin{tabular}{lrrr}
\hline & \multicolumn{3}{c}{ Component } \\
\cline { 2 - 4 } & PC1 & PC2 & PC3 \\
\hline Moisture & -0.06 & 0.37 & -0.54 \\
$\mathrm{pH}$ & 0.44 & -0.05 & 0.31 \\
$\mathrm{EC}$ & 0.11 & 0.27 & -0.07 \\
Total C & -0.44 & 0.33 & 0.16 \\
Total N & -0.42 & 0.28 & 0.06 \\
$\mathrm{C}$ to N ratio & -0.31 & 0.30 & 0.24 \\
Exchangeable Mg & -0.04 & 0.18 & 0.64 \\
Exchangeable Ca & 0.40 & 0.33 & 0.28 \\
Exchangeable Na & 0.26 & 0.44 & -0.08 \\
Exchangeable K & 0.31 & 0.43 & -0.17 \\
Eigenvalue & 3.29 & 2.34 & 1.55 \\
\% of total variance* & 32.9 & 56.3 & 71.8 \\
\hline
\end{tabular}

${ }^{*}$ Calculated as cumulatives valure.

\subsection{Relationship Between Biomass and Sap Production}

Figure 6 shows the relationship between the biomass of a frond surrounding a fruit stalk with on-going sap collection and mean daily sap production (DSP). It shows that the higher the frond biomass, the more sap is produced. The relationship is expressed as

$$
\text { Mean sap production }(\mathrm{ml} / \text { day })=17.6 x \text { frond biomass }(\mathrm{kg})+256.1\left(r^{2}=0.48\right)
$$

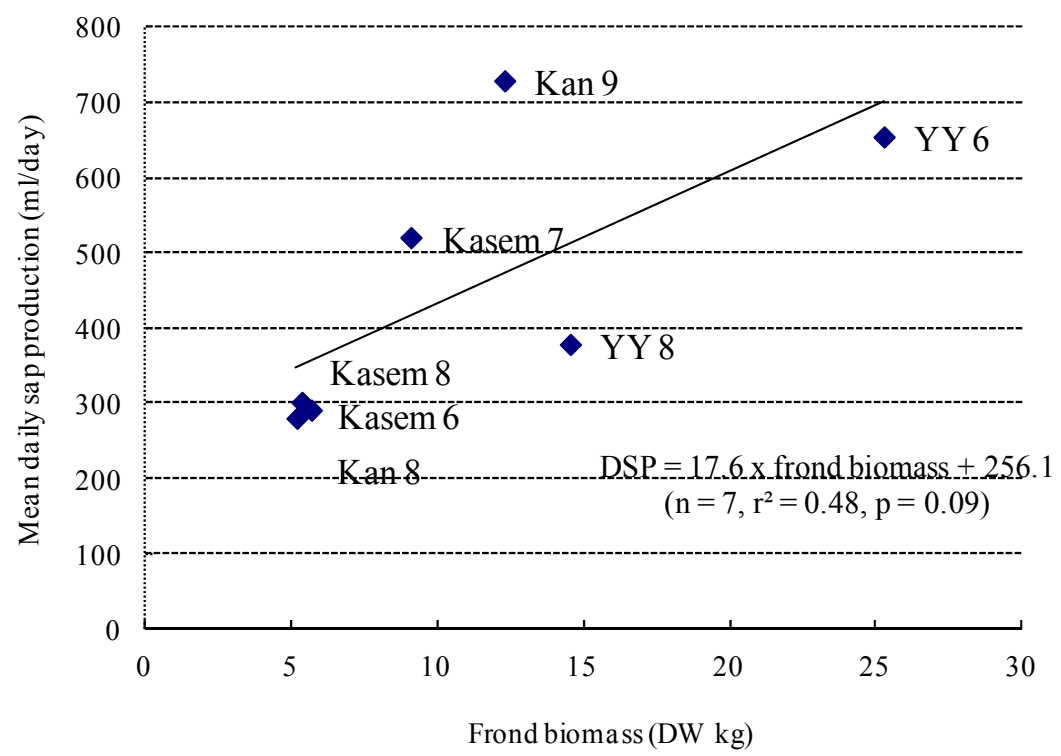

Figure 6. Relationship between frond biomass $(\mathrm{kg})$ and mean daily sap production ( $\mathrm{ml} /$ day)

A relationship was found between above-ground biomass and mean daily sap production (DSP) in five farms (Figure 7). Using the sap monitoring results reported in part I of this study and the measured above-ground biomasses obtained in this study, mean sap production can be expressed by above-ground biomass as

$$
\text { Mean sap production }(\mathrm{ml} / \text { day })=11.4 \times \text { above-ground biomass }(t / h a)\left(r^{2}=0.57\right)
$$




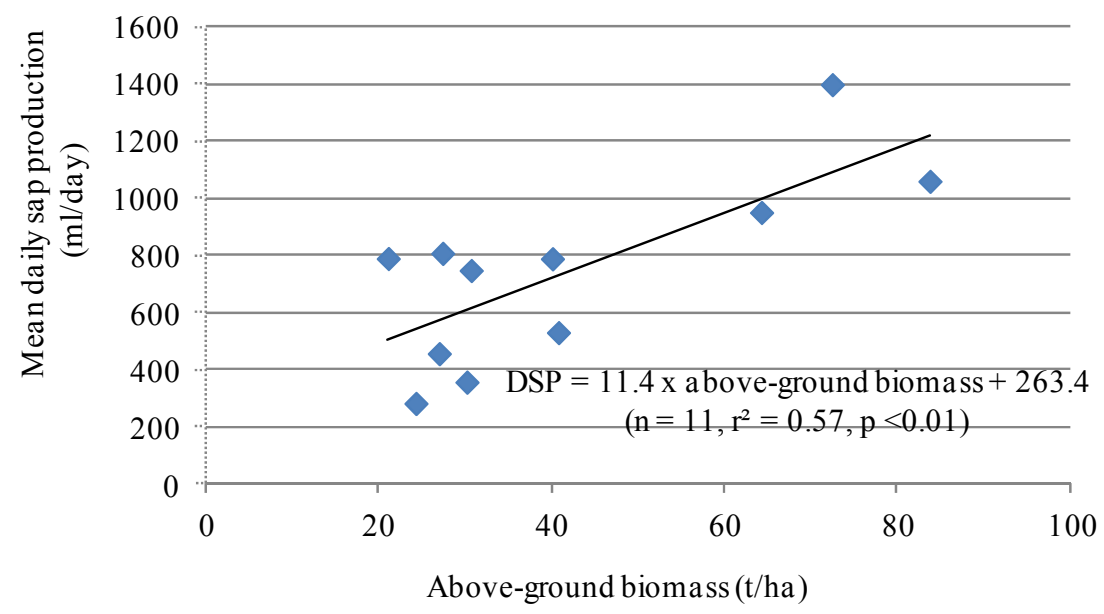

Figure 7. Relationship between nipa above-ground biomass ( $\mathrm{t} / \mathrm{ha})$ and mean daily sap production ( $\mathrm{ml} / \mathrm{day})$. Nipa above-ground biomass was measured in five farms

\subsection{Effects of Soil Factors on Sap Production}

Stepwise multiple regression analysis was performed to obtain a model for prediction of nipa sap daily production. In this analysis, daily sap production which was monitored in five farms, was used as a dependent variable, and standardized scores of the three PCs from PCA were used as independent variables. The most appropriate model obtained with a $\mathrm{p}$ value of $<0.05$ provided the following equation:

$$
\text { Daily sap production }=609.7-92.9 \times P C 1-58.5 \times P C 2\left(r^{2}=0.93\right)
$$

The equation (4) implies that organic matter and nitrogen contents as well as brackish water may influence on amounts of daily sap production.

\section{Discussion}

\subsection{Characteristics of Nipa Plantation Stands}

As a conventional practice, farmers practice thinning and control the number of fronds because an excessive number of fronds are believed to reduce sap production. However, the number of fronds is not likely to be a significant factor for sap production, as shown by the observation that Yong Yot's farm has a smaller number of fronds than Sompong's farm, but the sap production was higher in Yong Yot's farm.

Density is also considered to be a factor that determines nipa stand productivity. Sap production is reported to be higher in wider spacing, that is, a lower density (Dalibard, 1999). Natural nipa stands have a density range between 1,025 and 6,400 clusters per hectare (Roazainah \& Aslezaeim, 2010). When reduced to 500 clusters per hectare, sap production will increase (Dalibard, 1999). Cluster density in this study was in the range between 725 and 1,050. Cluster density was almost similar in Sompong and Yong Yot's farms, but their sap productions were rather different. Therefore, density may also not be a major criterion that determines sap yield.

H-DBH ratio $[\mathrm{H}(\mathrm{m}) / \mathrm{DBH}(\mathrm{cm}) \times 100]$ is used as the index of tree form. By this ratio, the form of a nipa frond in Kovit's farm was defined as having a roly-poly shape, which was in contrasts to the slim fronds in other farms. Considering that the fronds in Kovit's farm are slow-growing (Part I; Figure 8), it is probable that the nipa plant in Kovit's farm is a variety different from those in the other farms.

\subsection{Above-Ground Biomasses}

The above-ground biomasses were 20-30 t/ha in most of the farms, whereas Kovit's farm showed the highest above-ground biomass $(83 \mathrm{t} / \mathrm{ha})$. The biomass of oil palm FFB differs according to the plantation age. A 3-year-old oil palm plantation has above-ground biomasses of $17.9 \mathrm{t} / \mathrm{ha}$ in Indonesia, 21.3 in Malaysia, and 6.5 in the rest of world (FAO, 2010). For a mature plantation, the biomass is nearly 80 ton/ha (Khalid et al., 1999). A biomass of 75 ton/ha is reported for coconut palm (European Commission, 2009). Considering these, the nipa biomass is similar to that of a young oil palm plantation.

The biomass of the nipa plantation studied is controlled by the thinning of fronds. With $20-30 \mathrm{t} / \mathrm{ha}$ of standing biomass, a nipa farm could produce 3.2-6.5 t/ha of sugar yearly. Apparently, a higher biomass seems to produce 
more sap; but many of farmers thin fronds to maintain adequate number of fronds with the belief that excess number reduce sap production.

\subsection{Soil Properties of Nipa Stands}

Soil formation in nipa stands is characteristically determined by three separate factors, inflow of brackish water, organic matter, and topography, as indicated by PCA (Table 5), which would affect above-ground biomass and sap production.

The ground levels determined at Kovit, Yong Yot, and Sompong's farms were $19-31 \mathrm{~cm}$. This would lead to a high variance in EC, indicating that salt accumulates unevenly in a farm. In the correlation matrix of measured soil properties (Table 4), $\mathrm{pH}$ showed a statistically significant negative relationship with total $\mathrm{C}$ and total $\mathrm{N}$. This finding indicates that organic matter is decomposed when soil becomes dry, resulting in the decrease in $\mathrm{pH}$ (Table 4). Furthermore, a positive relationship of $\mathrm{pH}$ with exchangeable $\mathrm{Mg}$ content $(p<0.01)$ indicates that brackish water flows into a nipa farm, resulting in an increase in $\mathrm{pH}$. Inflow of brackish water does not directly determine the water content in soil. Topography is also another factor that affects water content because it affects the duration of water inundation in a farm.

\subsection{Effects of Biomass and Soil Properties on Sap Production}

Both the frond biomass surrounding fruit stalk and above-ground biomass are related to sap production. Frond biomass explained the variance of sap production by $48 \%$ (Equation (2)) and above-ground biomass explained by $57 \%$ (Equation (3)). Although the number of datasets is small (5), stepwise regression analysis showed that a model including soil properties could explain better sap production (Equation (4)). Sap production will increase by an increase of soil organic matter content and when the influence of brackish water decreases. This finding has a practical significance. Sap could be produced more when the farm is managed such that the influence of brackish water is reduced in a nipa farm.

\section{Conclusions}

The above-ground biomass of five nipa stands were quantified on the basis of the allometric relationship formulated for this study. The allometric equation for nipa frond biomass was expressed as $\log \mathrm{DW}=0.85 \mathrm{x} \log$ $\mathrm{D}^{2} \mathrm{~L}+1.54\left(\mathrm{r}^{2}=0.94\right)$, for which the L-DBH relationship was determined for each of the farms. The highest above-ground biomass was $83 \mathrm{t} / \mathrm{ha}$, whereas the average biomass in other farms was $32 \mathrm{t} / \mathrm{ha}$, which corresponds to the biomass of young oil palms in a plantation. The soils of nipa stands were characterized by a high variation of EC and a highly exchangeable Na. PCA showed that three factors, organic matter, salt content and brackish water were associated with soil properties. Fronds surrounding fruit stalk and above-ground biomasses explained sap production by $48 \%$ and $57 \%$, respectively; however, sap production could be better explained by $93 \%$ when soil properties are considered.

\section{Acknowledgements}

The research budget was fully provided by Kansai Electric Power Co., Inc., Japan. We would like to thank Mr. Ramón for frond measurement in the field. We also thank all the nipa farm owners, Mssrs. Kovit, Sompong, Yong Yot, Bunchoy, and Kan, for giving us the opportunity to conduct research in their farms.

\section{References}

Aholoukpè, H., Dubos, B., Flori, A., Deleporte, P., Amadji, G., Chotte, J. L., \& Blavet, D. (2013). Estimating aboveground biomass of oil palm: Allometric equations for estimating frond biomass. Forest ecology and management, 292, 122-129. http://dx.doi.org/10.1016/j.foreco.2011.07.008

Arachchi, L. V., \& Liyanage, M. D. S. (1997). Soil physical conditions and root growth in coconut plantations interplanted with nitrogen fixing trees in Sri Lanka. Agroforestry systems, 39(3), 305-318. http://dx.doi.org/10.1023/A:1005902628112

Auxtero, E. A., \& Shamshuddin, J. (1991). Growth of oil palm (Elaeis guineensis) seedlings on acid sulfate soils as affected by water regime and aluminium. Plant and Soil, 137(2), 243-257. http://dx.doi.org/10. 1007/BF00011203

Brakas, S. G., \& Aune, J. B. (2011). Biomass and carbon accumulation in land use systems of Claveria, the Philippines. In: Carbon Sequestration Potential of Agroforestry Systems, (pp. 163-175). Springer Netherlands. http://dx.doi.org/10.1007/978-94-007-1630-8_9

Corley, R. H. V., Gray, B. S., \& Ng, S. K. (1971). Productivity of the oil palm (Elaeis guineensis Jacq.) in Malaysia. Expl. Agric, 7,129-136. http://dx.doi.org/10.1017/S0014479700004907 
Dalibard, C. (1999). Overall view on the tradition of tapping palm trees and prospects for animal production. Livestock Research for Rural Development, 11(1). http://Irrd.cipav.org.co/Irrd11/1/dali111.htm

European Commission. (2009). Directive 2009/28/EC of the European parliament and of the council of 23 April 2009 on the promotion of the use of energy from renewable sources. Official Journal of the European Union, June $5^{\text {th }}$

Fangren, P., Baolong, H., \& Juhana, T. (1999). Productivity and nutrient cycling in an agroforestry ecosystem for interplant of pineapple and coconut. Journal of Forestry Research, 10(3), 163-167. http://dx.doi.org/10. $1007 / \mathrm{BF} 02855424$

FAO. (2010). FAOSTAT. Retrieved from http://faostat.fao.org/site/377/DesktopDefault.aspx?PageID=377\#ancor

Henson, I. E., \& Chai, S. H. (1997). Analysis of oil palm productivity. II. Biomass, distribution, productivity and turnover of the root system. Elaeis, 9(2), 78-92.

Khalid, H., Zin, Z. Z., \& Anderson, J. M. (1999). Quantification of oil palm biomass and nutrient value in a mature plantation. I. Above-ground biomass. Journal of Oil Palm Research, 11(1), 23-32.

Khalid, H., Zin, Z. Z., \& Anderson, J. M. (2000). Soil nutrient dynamics and palm growth performance in relation to residue management practices following replanting of oil palm plantations. Journal of Oil Palm Research, 12(1), 25-45.

Kitaya, Y., Jintana, V., Piriyayotha, S., Jaijing, D., Yabuki, K., Izutani, S., Nishimiya, A., \& Iwasaki, M. (2002). Early growth of seven mangrove species planted at different elevation in a Thai estuary. Trees, 16(2-3), 150-154. http://dx.doi.org/10.1007/s00468-002-0166-6

Komiyama, A., Santiean, T., Higo, M., Patanaponpaiboon, P., Kongsangchai, J., \& Ogino, K. (1996). Microtopography, soil hardness and survival of mangrove (Rhizophora apiculata BL.) seedlings planted in an abandoned tin-mining area. Forest Ecology and Management, 81, 243-248. http://dx.doi.org/10.1016/ 0378-1127(95)03591-5

Kosaki, T., \& Juo, A. S. R. (1989). Multivariate approach to grouping soils in small fields. I. Extraction of factors causing soil variation by principal component analysis. Soil Sci.Plant Nut. (Tokyo), 35, 469-477.

Matsui, N., Suekuni, J., Havanond, S., Nishimiya, A., Yanai, J., \& Kosaki, T. (2008). Determination of soil-related factors controlling initial mangrove (Rhizophora apiculata BL.) growth in an abandoned shrimp pond. Soil Sci Plant Nutr, 54, 301-309. http://dx.doi.org/10.1111/j.1747-0765.2007.00238.x

Morel, A. C., Saatchi, S. S., Malhi, Y., Berry, N. J., Banin, L., Burslem, D., Nilus, R., \& Ong, R. C. (2011). Estimating aboveground biomass in forest and oil palm plantation in Sabah, Malaysian Borneo using ALOS PALSAR data. Forest Ecology and Management, 262(9), 1786-1798.

Navarro, M. N. V., Jourdan, C., Sileye, T., Braconnier, S., Mialet-Serra, I., Saint-Andre, L., ... Roupsard, O. (2008). Fruit development, not GPP, drives seasonal variation in NPP in a tropical palm plantation. Tree physiology, 28(11), 1661-1674.

Roazainah, M. Z., \& Aslezaeim, N. (2010). A demographic study of a mangrove palm, Nypa fruticans. Scientific research and Essays, 5(24), 3896-3902.

SAS Institute Inc. (2009). JMP Version 8.0.2. Cary, N.C.

Shuit, S. H., Tan, K. T., Lee, K. T., \& Kamaruddin, A. H. (2009). Oil palm biomass as a sustainable energy source: a Malaysian case study. Energy, 34(9), 1225-1235.

Thenkabail, P. S., Stucky, N., Griscom, B.W., Ashton, M.S., Diels, J., Van Der Meer, B., \& Enclona, E. (2004). Biomass estimations and carbon stock calculations in the oil palm plantations of African derived savannas using IKONOS data. International Journal of Remote Sensing, 25(23), 5447-5472. http://dx.doi.org/10.1080/01431160412331291279

\section{Copyrights}

Copyright for this article is retained by the author(s), with first publication rights granted to the journal.

This is an open-access article distributed under the terms and conditions of the Creative Commons Attribution license (http://creativecommons.org/licenses/by/3.0/). 